УДК 657.421 .3

DOI: https://doi.org/10.37320/2415-3583/21.10

Прокопченко С.B.

головний науковий співробітник Український науково-дослідний інститут спеціальної техніки та судових експертиз

Служби безпеки Украӥни

ORCID: https://orcid.org/0000-0002-8338-4876

\title{
УРАХУВАННЯ ОСОБЛИВОСТЕЙ ОБЛІКУ ВИТРАТ СТВОРЕННЯ НЕМАТЕРІАЛЬНИХ АКТИВІВ У БЮДЖЕТНІЙ НАУКОВО-ДОСЛІДНІЙ УСТАНОВІ
}

\begin{abstract}
Одним із найважливіших об'єктів майна науково-дослідної установи є нематеріальні активи, які виступають джерелом як отримання конкурентних переваг, так і показником ефективності ї̈ діяльності. Створення нематеріальних активів у науково-дослідних установах має певні особливості, головною з яких є бюджетне фінансування. Під час дослідження та розроблення таких активів виникає чимало питань щчодо відображення в обліку витрат. У статті запропоновано підхід до розмежування етапів дослідження від етапу розроблення під час облікового відображення витрат на нематеріальні активи. Доведено, щзо ризик-орієнтовне управління та вдосконалення порядку обліку $і$ відображення у звітності витрат дає можливість отримати об 'єктивну й якісну інформачію щуодо вартості створених об 'єктів нематеріальних активів.
\end{abstract}

Ключові слова: науково-дослідна установа, нематеріальний актив, дослідження, розроблення, витрати.

Постановка проблеми. Нематеріальні активи сприяють підвищенню вартості установи та росту іiі інноваційної привабливості. Інвестиції в Україні у нематеріальні активи протягом останніх 15 років становили близько 2-4\% усіх капітальних інвестицій, а частка видів діяльності, що відносяться до високотехнологічних і середньотехнологічних, в обсязі реалізованої промислової продукції на прикладі 2017 р. становила $11,3 \%$ [1]. Для виправлення ситуації необхідний розвиток видів діяльності 3 високою наукоємністю, тобто необхідно забезпечити перехід від низькотехнологічної ресурсної до високотехнологічної інноваційної економіки, а в реалізації цієї державної політики активну участь приймають науково-дослідні установи, що забезпечують розвиток виробництва інтелектуальних продуктів, включаючи можливість їх комерціалізації як в Україні, так і світі.

Інтелектуальним продуктом науково-дослідної установи є нематеріальні активи, до яких відносять об'єкти права промислової власності (винаходи, корисні моделі тощо), знаки для товарів і послуг та об'єкти авторського права (монографії, посібники, методичні рекомендації, конструкторська документація тощо). При цьому головна особливість нематеріальних активів у науково-дослідних установах полягає у тому, що такі активи створюються за рахунок коштів бюджету України. Бюджетне фінансування залишається одним із головних фінансових інструментів науково-технічної політики та вимагає чіткого володіння достовірною і повною економічною інформацією, що формується у процесі ведення бухгалтерського обліку.

У процесі організації обліку витрат важливим аспектом для бухгалтера є необхідність чітко розмежувати етап дослідження від етапу розроблення, визначити можливість отримання нового продукту чи віднести понесені витрати на витрати звітного періоду, тому актуальним завданням $є$ дослідження облікового відображення витрат на дослідження та розробки.
Аналіз останніх досліджень і публікацій. Питання організації обліку витрат у своїх працях досліджували І.П. Житна [2], П.О. Куцик [3], I.I. Криштопа [4], С.Ф. Легенчук [5], Л.О. Кирильєва [6], Т.Я. Сенчук [7] та ін. Дослідження вчених спрямовані на вирішення проблем обліку витрат під час створення нематеріальних активів у виробничих підприємствах. Тоді як наукові установи, які займаються дослідженнями та розробленням нових видів науково-технічної продукції, мають певні особливості діяльності, що має визначальний вплив на організацію обліку витрат під час їх створення. Окремі аспекти обліку витрат в установах НААН України досліджував Н.А. Чугрій [8]. Незважаючи на це, питання особливостей обліку таких витрат під час дослідження та розроблення в науково-дослідній установі недостатньо досліджено.

Мета статті полягає в обгрунтуванні основних проблемних аспектів визначення вартості нематеріальних активів для контролю етапів досліджень та розробок як складника функції системи управління створенням науково-технічної продукції.

Виклад основного матеріалу. У сучасній обліковій практиці гостро стоїть питання щодо організації бухгалтерського обліку та контролю витрат на дослідження та розроблення. Відсутність достовірної інформації щодо розподілу витрат за цими етапами, методики обліку таких витрат тягне за собою зниження достовірної облікової інформації та неможливість ефективного управління нематеріальними активами. Аналіз нормативно-правової бази з обліку нематеріальних активів [9] виявив, що в ньому відсутнє пояснення, які саме витрати слід відносити до етапу дослідження, а котрі - до етапу розроблення.

Національні стандарти бухгалтерського обліку містять визначення термінів «дослідження» та «розроблення» [9-11]. За результатом аналізу термінів можна відрізнити етап дослідження за такими кри- 
теріями: заплановані установою, мають теоретичний характер, мета - отримання нових знань, наслідком може бути науковий результат. Водночас етапу розроблення притаманні такі критерії: прикладний характер, застосування вже отриманих результатів дослідження, мета - отримання нового продукту, наслідком може бути науково-прикладний результат. Згідно з вимогами державних стандартів, наукові (науково-прикладні) результати оформлюються у вигляді звітної науковотехнічної документації.

Схема формування витрат на створення об'єктів права інтелектуальної власності науково-дослідною установою в разі проведення науково-дослідних i дослідно-конструкторських робіт матиме вигляд, наведений на рис. 1.

Науково-дослідні установи самостійно визначають перелік витрат за етапами дослідження та розроблення з відображенням зазначеного у їхній обліковій політиці. Окремо слід звернути увагу на необхідність передбачати витрати на створення об'єктів права інтелектуальної власності як під час виконання дослідно-конструкторських робіт, так і під час проведення науково-дослідних робіт. Фактичним завершенням робіт за етапами, згідно 3 [8], є зарахування на баланс і використання придбаних (створених) об'єктів нематеріальних активів на підставі відповідного первинного документа. При цьому в первинному документі зазначаються назви документів, згідно з якими такий об'єкт нематеріальних активів уводиться в господарський обіг, зокрема патент, свідоцтво, ліцензійний договір, договір про створення за замовленням і використання об'єкта права інтелектуальної власності, договір про передання виключних майнових прав інтелектуальної власності тощо.

Зважаючи на МСБО 38 «Нематеріальні активи» [11], суб'єкт господарювання повинен довести щодо:

- технічної можливості завершення створення нематеріального активу так, щоб він був придатний до використання або продажу;

- свого наміру завершити створення нематеріального активу та використання або продати його;

- можливості нематеріального активу генерувати ймовірні майбутні економічні вигоди;

- наявності відповідних технічних, фінансових та інших ресурсів для завершення розроблення та використання чи продажу нематеріального активу;
- своєї здатності достовірно оцінити видатки, які відносяться до нематеріального активу протягом його розроблення.

Водночас витрати, пов'язані з придбанням (створенням) активу, який не відповідає критеріям визнання нематеріальним активом, визнаються витратами того періоду, протягом якого вони були здійснені, без визнання таких витрат у майбутньому нематеріальним активом.

Слід зауважити, що національні стандарти обліку не пояснюють, як саме установа повинна продемонструвати виконання цих критеріїв для визнання нематеріального активу в результаті розроблення.

В.В. Биба і Р.А. Міщенко у своєму дослідженні наводять аргумент щодо списання витрат на етапі дослідження на витрати звітного періоду відсутністю можливості у суб'єкта господарювання продемонструвати існування нематеріального активу, який генеруватиме ймовірні майбутні економічні вигоди [12, с. 41]. Варто відзначити, що стандарти бухгалтерського обліку не містять інформації щодо кінцевого терміну припинення капіталізації нематеріального активу. Тому закономірно вважати, що капіталізація припиняється тоді, коли нематеріальний актив довели до цільового використання.

Для вдосконалення облікового відображення витрат на дослідження та розроблення нематеріальних активів необхідно розуміти два основні кардинально відмінних підходи:

1)визнання нематеріального активу, тобто капіталізація витрат на його створення;

2)невизнання на окремому рахунку виникнення нового нематеріального активу, а списання витрат на його створення на фінансові результати.

Сьогодні в чинних національній та міжнародній моделях облікового регулювання наявний один чи іншій підхід або їх сполучення.

На думку Т.Я. Сенчук [7 с. 348], якщо підприємство створює нематеріальний актив, який планується в подальшому зареєструвати згідно з вимогами чинного законодавства, та ймовірність ризику отримання негативного результату є низькою, то витрати на таке розроблення слід обліковувати у складі капітальних інвестицій у нематеріальні активи. У разі встановлення високого ступеня ймовірності ризику отримання

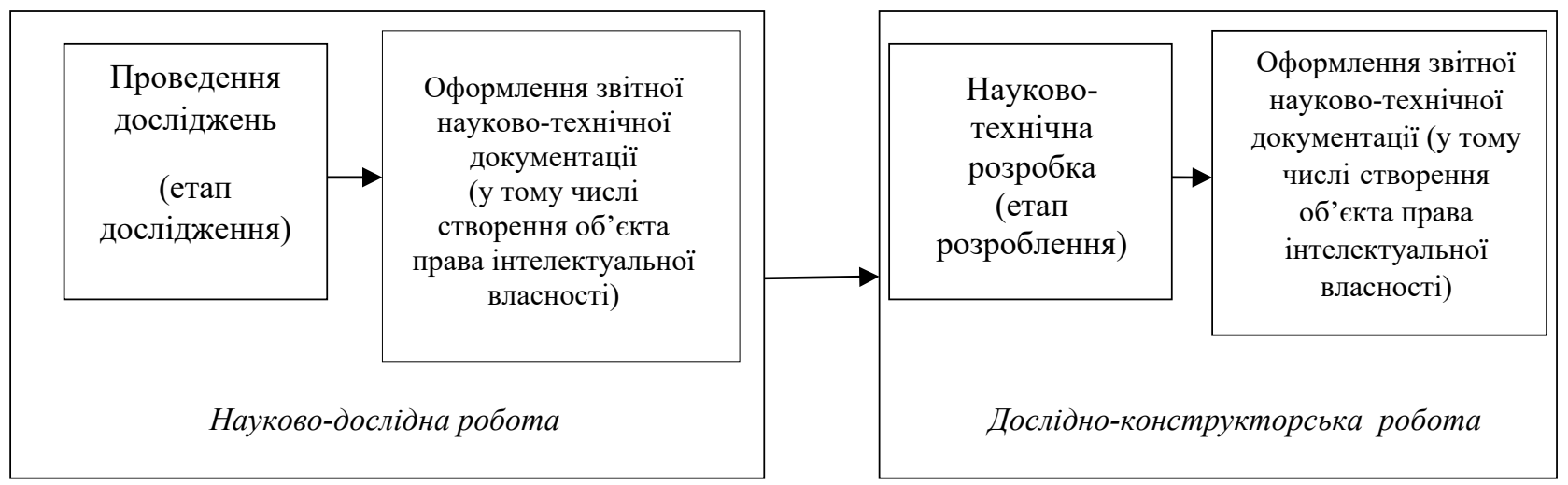

Рисунок 1 - Етапи формування витрат на створення науково-технічної продукції в науково-дослідних установах 
негативного результату проведення науково-дослідних та дослідно-конструкторських робіт витрати на дослідження та розроблення доцільно списувати на витрати звітного періоду.

Під час удосконалення політики (методики) бухгалтерського обліку витрат на дослідження і розроблення та їх відображення у фінансовій звітності в першу чергу необхідно зрозуміти їх важливість у діяльності науково-дослідної установи, зокрема чи існує певна залежність такого об'єкта обліку з результатами основної діяльності науково-дослідної установи в умовах сьогодення.

Автор уважає за необхідне під час планування витрат на дослідження та розроблення впровадження ризик-орієнтовного підходу відповідно до ДСТУ ISO 31000:2018 «Менеджмент ризиків» [13] під час стратегічного планування та актуалізації політики обліку витрат як підприємств, так і науково-дослідних установ.

У ризик-орієнтованому підході функціонування системи управління розглядається поняття прийнятності ризику - критерію виявлення характеру та ступеня ризику, які можуть використовуватися у відношенні до конкретної мети. Такі критерії визначаються шляхом вибору методології визначення величини ризику або пов'язаних із ним параметрів одночасно 3 установленням допустимих значень, які $є$ неприйнятними для конкретного ризику. У науково-дослідних установах під час дослідження та розроблення створюють науково-технічну продукцію систематично, тому в обліковій політиці (методиці) необхідно чітко обумовити критерії ризику, за якими результати науковотехнічної діяльності можуть визнаватися чи не визнаватися нематеріальними активами.

Висновки. У результаті дослідження встановлено, що з недостатнім урегулюванням механізму облікового відображення витрат на етапах дослідження та розроблення під час визначення вартості створених нематеріальних активів виникає чимало питань. Своєю чергою, ризик-орієнтовне управління та вдосконалення порядку обліку і відображення у звітності витрат дає можливість отримати об'єктивну й якісну інформацію щодо вартості створених об'єктів нематеріальних активів.

Рекомендовано науково-дослідним установам визначати перелік витрат у розрізі етапів дослідження та розроблення, а також чіткі критерії визнання нематеріальних активів і зафіксувати це в обліковій політиці. Зазначене допоможе уникнути помилок під час оцінки та постановки на баланс створених нематеріальних активів. Застосування цих критеріїв за ризикорієнтованого функціонування системи управління науково-дослідною установою забезпечить гнучкість фінансового та бухгалтерського обліку та дасть користувачу повну і правдиву інформацію про стан таких об'єктів.

\section{Список використаних джерел:}

1. Розпорядження Кабінету Міністрів України від 10 червня 2019 № 526-р «Про схвалення Стратегії розвитку сфери інноваційної діяльності на період до 2030 року». URL: https://zakon.rada.gov.ua/laws/show/526-2019-p\#Text.

2. Житная И.П., Манухина М.Ю. Учет затрат на научно-исследовательские и опытно-конструкторские работы. Вісник СНУ ім. В. Даля. 2004. № 3(74). С. 20-21.

3. Куцик П.О., Чабанюк О.М. Організація контролю витрат в системі управління санаторно-курортними установами. Вісник Житомирського державного технологічного університету. Економічні науки. 2010. № 3(53). С. $143-149$.

4. Криштопа I.I. Облік витрат на науково-дослідні та дослідно-конструкторські роботи. URL: http://www.rusnauka.com/15 APSN_2010/Economics/67862.doc.htm.

5. Легенчук С.Ф., Очередько В.Р. Внутрішньо створені нематеріальні активи: особливості визнання та напрями удосконалення бухгалтерського обліку. Проблеми теорії та методології бухгалтерського обліку, контролю $і$ аналізу. 2020. Вип. 2(46). С. 129-135.

6. Кирильєва Л.О., Самойлова Є.О. Проблемні аспекти обліку витрат на дослідження та розробки в закладах ресторанного господарства. Економічна стратегія і перспективи розвитку сфери торгівлі та послуг. 2012. № 1(1). С. 129-135.

7. Сенчук Т.Я. Організація обліку витрат на дослідження та розробки. Міжнародний збірник наукових праць. 2010. № 3(21). С. 346-351.

8. Чугрій Н.А. Особливості обліку витрат на етапі дослідження та розроблення нематеріальних активів у науково-дослідних установах НААН України. Науковий погляд: економіка та управління. 2018. № 2(60). С. 196-203.

9. Національне положення (стандарт) бухгалтерського обліку в державному секторі 122 «Нематеріальні активи» : Наказ Міністерства фінансів України від 12.10.2010 № 1202. URL: http://zakon.rada.gov.ua/laws/show/z1018-10.

10. Положення (стандарт) бухгалтерського обліку 8 «Нематеріальні активи» : Наказ Міністерства фінансів України від 18.10.1999 № 242. URL: http://zakon.rada.gov.ua/laws/show/z0750-99.

11. Міжнародний стандарт бухгалтерського обліку 38 «Нематеріальні активи». URL: https://zakon.rada.gov.ua/laws/ show/929_050;\#Text.

12. Биба В.В., Міщенко Р.А. Теорія і практика обліку витрат на дослідження та розробку нематеріального активу. Наукові праиі Полтавської державної аграрної академії. 2012. С. 39-46.

13. ДСТУ ISO 31000:2018 Менеджмент ризиків. Принципи та настанови (ISO 31000:2018, IDT) [Чинний від 2019-01-01] ДП «УкрНДНЦ», 2019. 42 с.

\section{References:}

1. Rozporiadzhennia Kabinetu Ministriv Ukrainy vid 10 chervnia 2019 № 526-r «Pro skhvalennia Stratehii rozvytku sfery innovatsiinoi diialnosti na period do 2030 roku» [On approval of the Strategy for the development of innovation for the period up to 2030]. Available at: https://zakon.rada.gov.ua/laws/show/526-2019-p\#Text.

2.Zhytnaia Y.P., Manukhyna M.Yu. (2004) Uchet zatrat na nauchno-yssledovatelskye i optno-konstruktorskye raboti [Cost accounting for research and development work]. Visnyk SNU im. V. Dalia, no. 3 (74), pp. 20-21.

3. Kutsyk P.O., Chabaniuk O.M. (2010) Orhanizatsiia kontroliu vytrat v systemi upravlinnia sanatorno-kurortnymy ustanovamy [Organization of cost control in the management system of sanatoriums]. Visnyk Zhytomyrskoho derzhavnoho tekhnolohichnoho universytetu. Ekonomichni nauky. Zhytomyr: ZhDTU. No. 3 (53), pp. 143-149. 
4. Kryshtopa I.I. Oblik vytrat na naukovo-doslidni ta doslidno-konstruktorski roboty [Accounting for research and development costs]. Available at: http://www.rusnauka.com/15_APSN_2010/Economics/67862.doc.htm.

5. Lehenchuk S.F., Ocheredko V.R. (2020) Vnutrishno stvoreni nematerialni aktyvy: osoblyvosti vyznannia ta napriamy udoskonalennia bukhhalterskoho obliku [Internally created intangible assets: features of recognition and areas of improvement of accounting]. Problemy teorii ta metodolohii bukhhalterskoho obliku, kontroliu i analizu, vol. 2 (46), pp. 129-135.

6. Kyrylieva L.O., Samoilova Ye.O. (2012) Problemni aspekty obliku vytrat na doslidzhennia ta rozrobky v zakladakh restorannoho hospodarstva [Problematic aspects of accounting for research and development costs in restaurants]. Ekonomichna stratehiia $i$ perspektyvy rozvytku sfery torhivli ta posluh, no. 1 (1), pp. 129-135.

7. Senchuk T.I. (2010) Orhanizatsiia obliku vytrat na doslidzhennia ta rozrobky [Organization of accounting for research and development costs]. Mizhnarodnyi zbirnyk naukovykh prats, no. 3 (21), pp. 346-351.

8. Chuhrii N.A. (2018) Osoblyvosti obliku vytrat na etapi doslidzhennia ta rozroblennia nematerialnykh aktyviv u naukovodoslidnykh ustanovakh NAAN Ukrainy [Features of cost accounting at the stage of research and development of intangible assets in research institutions of NAAS of Ukraine]. Naukovyi pohliad: ekonomika ta upravlinnia, no. 2 (60), pp. 196-203.

9. Natsionalne polozhennia (standart) bukhhalterskoho obliku v derzhavnomu sektori 122 «Nematerialni aktyvy» [Intangible assets]. Nakaz Ministerstva finansiv Ukrainy vid 12.10.2010 r. № 1202. Available at: http://zakon.rada.gov.ua/laws/show/z1018-10.

10. Polozhennia (standart) bukhhalterskoho obliku 8 «Nematerialni aktyvy» [Intangible assets]. Nakaz Ministerstva finansiv Ukrainy 18.10.1999 r. № 242. Available at: http://zakon.rada.gov.ua/laws/show/z0750-99.

11. Mizhnarodnyi standart bukhhalterskoho obliku 38 «Nematerialni aktyvy» [Intangible assets]. Available at: https://zakon.rada.gov.ua/ laws/show/929_050;\#Text.

12. Byba V.V., Mishchenko R.A. (2012) Teoriia i praktyka obliku vytrat na doslidzhennia ta rozrobku nematerialnoho aktyvu [Theory and practice of accounting for research and development of intangible assets]. Naukovi pratsi Poltavskoi derzhavnoi ahrarnoi akademii, pp. 39-46.

13. DSTU ISO 31000:2018 Menedzhment ryzykiv. Pryntsypy ta nastanovy [Risk management. Principles and guidelines ] (ISO 31000:2018, IDT) 2019-01-01 DP «UkrNDNTs», 2019, 42 p. (Informatsiia ta dokumentatsiia)

Prokopchenko Serhii

The Ukrainian Scientific and Research Institute of Special Equipment and Forensic Expertise of the Security Service of Ukraine

\section{TAKING INTO ACCOUNT THE FEATURES OF ACCOUNTING COSTS OF CREATION OF INTANGIBLE ASSETS IN THE BUDGET RESEARCH INSTITUTION}

The need for more active and efficient use of intangible assets in the activities of enterprises, which in such conditions become the main source of value creation requires more careful consideration of the cost of creation of tangible assets. Intangible assets are one of the most important assets of research institutions, which are a source of both competitive advantage and efficiency. The main feature of the creation of intangible assets in research institutions is budget funding. When creating such assets, there are many difficulties in accounting for costs. The article considers the recommendations of accounting standards for intangible assets and proposes an approach to distinguishing stages of research and development in research and development, including the need to create an object of intellectual property rights for each type of work, and considered two basic radically different approaches in the reflection of cost accounting. The principle of determining the deadline for termination of capitalization of an intangible asset is proposed. Recognized the need to implement a risk-based approach in planning expenditures for research and development in accordance with the recommendations of ДСТУ ISO 31000:2018 (ISO 31000:2018, IDT) «Risk management - Guidelinesin» strategic planning and updating the cost accounting policy of both enterprises and research institutions. It is recommended that research institutions determine the list of costs in terms of stages of research and development, as well as clear criteria for the recognition of intangible assets with their teaching in accounting policy. his will help to avoid mistakes in the valuation and balance sheet of intangible assets. The application of these criteria in the risk-oriented operation of the management system of the research institution will provide flexibility in financial and accounting and will provide the user with complete and accurate information about the status of such facilities. The risk criteria according to which the results of scientific and technical activities may or may not be recognized as intangible assets in accounting policy must be clearly defined.

Key words: intangible asset, research, development, costs, research institution.

JEL Classification: 